\title{
A Study on Personal Fashion Color Choices in Manicures and Pedicures
}

\author{
Sun-he Moon ${ }^{1}$, Young-Sam Kim ${ }^{2 *}$ \\ ${ }^{1}$ Department of Cosmetics Engineering, Konkuk University, Seoul, Korea \\ ${ }^{2}$ Department of Image Industry, Graduate School of Engineering, Konkuk University, Seoul, Korea
}

\author{
*Corresponding author: Young-Sam Kim, \\ Department of Image Industry, Graduate \\ School of Engineering, Konkuk University, \\ 120 Neungdong-ro, Gwangjin-gu, Seoul \\ 05029. Korea \\ Tel.: +82 24500463 \\ Fax: +82 24506154 \\ Email: gracenelen@konkuk.ac.kr
}

Received August 30, 2021

Revised November 04, 2021

Accepted November 12, 2021

Published December 30, 2021

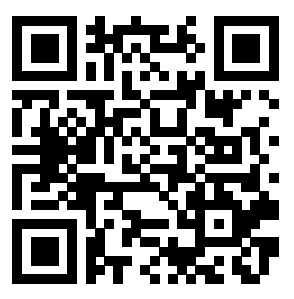

\begin{abstract}
Purpose: The purpose of this study was to offer useful information for improving women's beauty self-images by analyzing personal color choices in women's fashions and determining the correlation between color matching and personal fashion color choices in manicures and pedicures. Methods: The research subjects included 32 women aged 20-50 years who lived in capital area and whose personal color fashion choices were determined. The data were analyzed with frequency analysis, a $x^{2}$-test, and a one-way ANOVA using SPSS WIN 25.0. Results: Considering the personal color choices, they were high in "summer types" for $L^{*}$ values of skin, high in "winter types" for $L^{*}$ values of hands and feet, and high in "fall types" for values $a^{*}$ and $b^{*}$ of skin, hands, and feet. Also, with regard to matching tones for hands and feet, the personal color choices were mostly "spring types" with warm spring-type tones, summer types with cool summer-type tones, "fall types" with warm fall-type tones, and "winter types" with cool winter-type tones. Conclusion: The results of this study suggested the matched tones for hands and feet are similar to the personal color fashion choices. These findings support a theoretical basis for harmonious color matching when choosing colors in manicure and pedicure nail art. The findings of this study may assist with beauty styling and self-images of women in this fashion era.
\end{abstract}

Keywords: Personal color, Nail, Pedicure, Beauty styling, Fashion

\section{Introduction}

21세기 뷰티는 예술로 인식되는 가운데 뷰티스타일링은 예술의 한 표현으로서 이미지에 따른 소통의 역할을 하고 있다. 이러한 이미지 를 표현하는데 있어 헤어, 메이크업, 네일과 패션은 함께 조화를 이 루어 연출되어야 이상적인 뷰티스타일링을 이루어 낼 수 있다(Jung, 2013). 뷰티 디자인은 인간의 아름다움과 삶의 방향을 정서적으로 소 통하는 커뮤니케이션으로써 스타일과 색채와 함께 공존하며 좋은 이 미지는 기업의 상품 이미지는 물론 개인의 가치 또한 높여준다. 이 러한 뷰티 디자인은 감성 이미지 표현이 중요하다. 현대인들은 각자 의 자신에 대한 표현과 개성을 개발하는 양상을 나타내고 있으며, 특 히 공간에서 신체의 표현력은 매우 중요하고 색채에 의한 이미지 연 출은 각자의 긍정적 이미지를 부각시키므로 사회적 관계성을 얻을 수 있다. 특히 다른 사람과 다른 본인만의 아름답게 보이고자 하는 개성
의 표현은 여성들의 이미지와 뷰티스타일 형성에서 색채에 대한 시각 적이고 외향적인 것에 중요한 의미를 부여하고 있다. 자신의 이미지 가 타인이 보는 관점에 의해 중요하게 판단됨에 따라(Kim, 2016)개 성을 표출하기 위하여 여성들은 의상, 액세서리, 헤어, 메이크업, 네 일아트를 도구로 활용하고 있다(Woo \& Kim, 2011). 이러한 측면에 서 자신을 긍정적으로 평가받을 수 있는 개인적 이미지에 있어 색채 는 중요한 자산이며 커뮤니케이션의 수단으로 활용되고 있으며 이미 지를 포함한 개인의 다른 특성까지도 긍정적인 요인으로 개성의 자연 스러운 표현과 사회적 대인관계에 있어 매우 중요한 소통의 기능을 하고 있다. 특히 컬러는 자아를 표현하는데 있어 가장 확실한 수단으 로서(Oh \& Cho, 2018) 사회활동에 맞는 자신의 이미지 연출과 특성 을 표현할 수 있다(Byun \& Lee, 2019). 특히 메이크업, 네일아트, 의 상, 헤어 색채는 선택에 있어서 타인에게 미치는 심리적 영향력이 매 우 크기 때문에 개인에게 맞는 조화로운 색의 미적 표현은 매우 중요 
한 부분이다.

현대사회에서 외모가 가지는 경쟁력이 중요해지면서 빠른 시간에 자신의 이미지를 개선하여 좋은 이미지를 연출하고, 개성을 표현하 는 방법으로 색채에 대한 관심이 높아지고 있다(Lee \& Kim, 2020). 이미지는 주관적 판단으로 이루어지지만 그것을 형성하고 좌우하는 역할 중의 하나가 색채이다(Kim, 2016). 특히 색채는 자아를 표현하 는데 있어 가장 확실한 수단으로서(Oh \& Cho, 2018), 사람의 감정 을 자극하는 색채만의 고유의 언어적-시각적 이미지로 그 중 네일아 트 분야에서 이미지를 결정하는데 매우 중요한 요소로 작용하고 있 다(Cho, 2018). 이러한 색채는 시각적으로 이미지를 전달할 수 있고, 감성 이미지의 한 부분으로서 개인의 가치로 표현하는 도구로 활용한 다(Choi \& Suh, 2020). 따라서 색채는 다양하고 보편적인 이미지 특 성을 조형언어로 표현할 수 있으며 이러한 특성은 네일아트 스타일에 서 충분히 다양하게 표현할 수 있다(Cho, 2018). 네일아트는 시각적 으로 나타나는 색채(color)를 사용하여 손과 발에 결점을 보완하고 아 름다움을 표현하는 방법으로서, 개인이 타고난 외모에 조화로운 색 채를 배색하는 행위이다(Song et al., 2014). 색채의 효과는 사람들 의 이미지와 외모를 변화시키며, 그것으로 인한 심리적 상승효과와 모든 일에서 자신감과 기쁨을 주는 긍정적인 사고를 갖게 한다.

Jeun \& Shim (2012)은 네일아트에서의 색채는 시각적 의미만의 변화가 아닌 하나의 트렌드(trend)가 다양한 다른 영역의 트렌드와 접목해서 변화되는 과정으로 형성된다고 하였고, 트렌드와 경향을 수립-제시하는 기관은 예술의 흐름과 사회현상, 문화 현상, 소비자 심리 등을 분석하여 시즌 별로 특정한 이미지를 부여하고, 시대 동향 에 맞는 색을 설정하여 트렌드를 예측한다고 하였듯이, 네일아트에 있어 색채 트렌드의 적용이 필요하다고 사료된다. 자신의 이미지 개 선을 위한(Im et al., 2017) 색채를 선택할 때 신체색과 조화를 이뤄 피부색이 아름답고 건강하게 보이는 색채를 퍼스널 컬러라고 하며, 이러한 퍼스널 컬러는 네일아트에 있어서 긍정적인 이미지 연출 및 아름다움에 대한 욕구를 충족시켜줄 수 있는 중요한 도구로 인식되어 가고 있다(Kim, 2011). 네일아트는 단순히 아름답게 보이기 위해 바 르는 것이 아닌 자기를 상징으로 표현하는 커뮤니케이션의 수단이며 자신의 이미지와 개성을 강화하는 역할을 한다(Kim \& Kim, 2014). 컬러는 네일아트의 도구로서 네일아트 분야에서도 한국인의 퍼스널 컬러 표준이 될 수 있는 연구가 지속적이어야 한다.

퍼스널컬러 진단의 경우 대부분의 소비자들이 스스로 파악한다는 것은 매우 어려운 일이며 매장에서 전문가의 조언이나 서비스를 통해 자신의 퍼스널컬러를 파악하는 것이 일반적이다. 이러한 시장 변화 에 미용 서비스업의 종사자는 전문적인 분야로써, 지식과 기술, 정보 의 증가에 맞춰 고객에게 미적 만족을 주는 업무의 수행이 필요하다 (Min et al., 2013). 퍼스널 컬러에 대한 연구를 통하여 소비자의 인 지도와 색채 선호도 조사는 한국 여성에 맞는 퍼스널 컬러 교육과 진 단의 매우 필요한 부분이다. 이러한 자신의 피부색에 대한 관심은 소 비자들을 위한 퍼스널컬러의 고도화된 연구와 세분화된 색채로서 상
호적 시너지 효과를 형성하며 시장의 경제적 규모를 확대하는 원동 력이 될 것이라 사료된다. 특히 한국인의 경우 피부색 분포가 일정한 밝기와 색조에 밀집되어 있기 때문에 육안으로 판단하는 데는 한계 가 있어 객관적인 판단을 위해서 측색이나 전문가의 육안 진단이 필 요하다(Lee et al., 2019). 신체색의 차이를 시각에만 의존하기 보다 (Moon \& Park, 2014), 객관적인 지표가 될 수 있는 데이터의 활용이 필요하다. 일반적으로 어울리는 색채의 평가는 대부분 감성적인 평 가에 의해 이루어지고 있으며, 지금까지의 선행연구들을 살펴보면, 어울리는 색상의 진단 방법으로 얼굴 피부색과 색상의 어울리는 정도 를 평가자의 감성적 평가에 따라 진단하는 관능평가방법을 사용하는 것이 보편적이다. 그러나 관능평가방법은 평가자의 주관성을 배제할 수 없어 일관적인 평가에 어려움이 있다. 이를 보완하기 위해서는 얼 굴색과(Lee \& Park, 2012).

신체 부위별 색을 체계적이고 객관적으로 연구하는 분석적 방법이 필요하다고 사료된다. 따라서 측색 평가 시 관능적 평가로는 얼굴 부 위인 볼과 손 그리고 발의 신체 부위 별 피부색 차이를 분석하고 패션 과 네일아트 그리고 패디아트 컬러의 차이를 분석적인 프로그램이 필 요하다. 네일아트는 색채에 대한 적용과 진단이 매우 중요하게 작용 하며 개개인 별 단점을 최소화하고 장점을 극대화하여 개인의 심리 적 만족감과 경쟁력 향상 그리고 자신감을 높여주는 요소로서 극대화 된다. 신체 부위 별 색채를 정확히 파악하여 자신에게 가장 조화롭고 잘 어울리는 부위 별 색에 맞혀 자아를 표현하고 개성 있는 스타일을 연출하는 것이 뷰티 스타일링 가장 중요한 요소로 작용한다. 감성적 반응은 피부색에 대한 색채 인지와 일반적인 색채의 인지 과정 그리 고 색채의 감성적 이론을 바탕으로 사용하여 그에 따른 차이점을 설 명하기에는 한계가 있다. 또한 패디아트는 네일아트의 세분화로 큰 경쟁력의 일환으로 자리 잡고 있지만 네일아트에 관한 선행연구만 극 한 되어 있어 패디아트에 관한 선행연구는 미흡한 실정이다. 이러한 네일아트 퍼스널컬러 시스템 적용은 일반 소비자들에게 개인별로 맞 춰진 정확한 색채를 제시하고 색채 전문가가 아닌 특별한 지식이 없 는 네일아티스트(nail artist)라도 조금 더 정확하고 쉽게 소비자들과 자신에게 어울리는 색채를 선택할 수 있는 방법을 제시함으로써, 색 채가 스타일과 개성을 표현하는데 실질적인 역할을 기여하는 부분 에 그 목적이 있다. 체계적이고 전문적인 진단 방법을 통해 개인에게 어울리는 네일 컬러를 선택할 수 있는 서비스 제공과(Lee \& Kwon, 2017) 감성 시대에 맞혀 색채의 중요성은 네일아트에서도 네일 컬러 와 패디컬러의 선택에 있어 자신의 퍼스널컬러에 어울리는 개성을 표 현하기 위한 색채의 선정은 중요한 역할을 한다. 자신만의 어울리는 색채를 신체 부위에 맞혀 선택하는 것은 자신의 이미지를 만들어가기 위한 중요한 요소로써 감성 시대의 흐름에 맞춰 본 연구에서는 퍼스 널컬러에 따른 패션과 네일 컬러, 그리고 패디컬러의 선택이 자신의 이미지 향상에 도움이 될 것으로 기대한다. 


\section{Methods}

\section{1. 연구대상자 및 기간}

본 연구는 수도권에 거주하는 20-50세의 여성을 대상으로 실험 전 피부에 영향을 끼치는 스테로이드 계통의 약 복용을 금지시키고, 피부의 질병이 있는 자, 피부과 시술을 받은 자, 인공 태닝을 받은 자, 해외 거주자, 기관생명윤리 위원회 심의에 의거 객관성을 담보하 기 어려운 학생을 제외한 32 명을 대상으로 건국대학교 기관생명윤리 위원회(IRB)의 연구 승인(7001355-202103-HR-427)을 받고 진행 하였으며 연구 대상자들에게 실험을 통해 연구하려는 목적과 절차 등 의 내용을 상세히 설명한 후 동의를 구하였다. 실험은 개별적으로 1 차 설문지에 응답을 한 후 실험을 받았으며, 실험 처지 종료 직후 곧 바로 2차 설문지에 대한 응답을 하였다. 실험기간은 2021년 5월 15 일부터 5 월 16 일까지 총 2 일간에 나누어 시행되었다.

\section{2. 측정 도구 및 방법}

1) 측정도구

본 연구에서는 측색평가(측색계측정), 시감평가(시감비색측정), 관능평가(진단천 측정평가)을 통하여 측정방법의 장•단점을 고려하 여 객관적이고 정확한 진단을 실시하였다. 즉, 퍼스널컬러는 여러 가 지 신체 피부색의 요소들을 점검 후 드레이핑을 사용하여 개인의 고 유한 신체 색과의 조화를 판단하여 종합적인 진단이 필요하다. 첫 번 째, 측색평가(측색계측정)는 퍼스널컬러 결과가 즉시 나오는 것은 아 니지만, 가장 과학적인 접근 방법으로 얼굴의 볼은 입술 뒤쪽과 눈동 자 중간부분의 위치를 선정, 손은 손가락 중지의 시작부위 뼈를 기준 으로 손 등을 위치로 선정, 발은 엄지 발가락의 발 등 뼈 부분을 선정 하여 3차례에 걸쳐 나눠서 측색하였으며 수치를 비교할 수 있는 유용 한 방법이다. 측색계에 물체에 빛을 입사하여 반사광과 광원부을 측 정하는 방법으로 색 측정의 과정은 절대적 측정값보다 색차의 측정을 비교하고 분석하는 색 영역에 적합한 측정 장비로 CUBE (Palette사. Australia)를 사용하여 국제조명위원회(International Commission on Illumination, CIE)에서 지정한 CIELab값을 추출하였다. 두 번째, 시감평가(시감비색측정)방법은 육안측정 방법으로 최대한 피부색과 근접하게 비교 측정하여 시감적으로 평가하는 측정방법으로 (주코코 리색체연구소(Korea)가 제공한 손톱 채색 화장 색상 진단판(제30-
1080827호)을 이용하여 4계절 tone값을 산출공식에 따라 수치를 산 출하고 분석하였다. 세 번째, 관능평가(진단천, 네일팁 측정평가)방 법은 일반적인 퍼스널컬러 진단 방법으로 사계절 유형의 대표적 색 상의 얼굴에는 진단 천을 드레이핑 하고 손과 발에는 사계절 유형의 팁을 이용하여 피부색이나 신체 부위 별 색상과 어울리는 색을 비교 하여 얼굴과 손 발의 피부색의 밝기, 명도 변화, 색상의 변화, 질감의 변화, 형태의 변화 등의 변화된 요인을 분석하여 어울리는 색의 조 화와 어울리지 않는 부조화를 평가하는 퍼스널컬러 유형을 분류하였 다. 본 연구의 측정도구는 Table 1 과 같다.

\section{2) 측정방법}

스마트 CUBE(Portable Color Digitizer, Palette, Australia) 측색 계의 측색 면을 알코올 솜을 이용하여 깨끗이 소독하고 세안한 상태 후 안정을 취한 대상자의 얼굴 볼 부위(눈꼬리와 입꼬리가 교차하는 부위), 핏줄이 안보이 부분의 손 등, 햇빛의 영향이 가장 적은 발가락 바로 윗 부분의 부위에 3 회 반복하여 측정하여 평균값을 적용하였다. 본 연구에 활용한 피부 측정값은 Palette사(Australia)가 제공하는 5 가지 컬러데이터 표시형식 중에서 $\mathrm{CIE}$ 의 $\mathrm{L}^{*}, \mathrm{a}^{*}, \mathrm{~b}^{*}, \mathrm{~b}^{*}-\mathrm{a}^{*}$ 형식을 취 하고, 이를 (주)코코리색체연구소가 개발한 tone값을 산출공식(제102090370호)에 대입하여 활용하였다. 연구대상자의 정확한 진단천 유형을 분석하기 위하여 컬러렌즈와 안경은 제거하고 어깨에 흰색 케 이프를 둘러 의상의 색상에 영향을 받지 않도록 외부와 환경을 표준 화하였다. 또한 날씨와 계절에 영향을 받지 않도록 동일한 환경을 만 들기 위해 자연광과 흡사한 $5000 \mathrm{k}$ 의 조명 램프를 사용하여 색온도 를 일정하게 만들었다.

\section{3) 네일 인조팁 제작과 색상 선정}

실험에 참여하는 대상자의 손톱과 발톱 사이즈의 표본을 측정하여 가장 근접한 크기의 일반 레귤러 풀팁을 선정하였다. 직접 네일 컬러 링을 하는 방법 대신 네일 컬러 팁을 사용하여 네일컬러를 바르고 지 우는 과정으로 인한 시간을 최소화하고 쉽게 탈부착이 가능한 컬러 팁을 사용하여 시간차를 줄여 실험 수행의 편이성과 신속성을 도모하 였다. 색상은 국내 컬러시스템인 $\mathrm{KS} 「 2009$ 년도 표준기술력향상사 업」은 한국색채표준디지털팔레트와 함께 한국산업표준(KSAB0062 색의 3속성에 의한 표시방법을 기본으로 색채 톤을 기준으로 한국인

Table 1. Personal color measuring tool

\begin{tabular}{ccc}
$\begin{array}{c}\text { Colorimetric evaluation }{ }^{1)} \\
\text { (Observation of colorimeter) }\end{array}$ & $\begin{array}{c}\text { Visual evaluation }^{2)} \\
\text { (Visual colorimetry) }\end{array}$ & $\begin{array}{c}\text { Sensory evaluation }^{3)} \\
\text { (Diagnosis drape evaluation) }\end{array}$ \\
\hline
\end{tabular}

${ }^{1)}$ Portable color digitizer; ${ }^{2}$ Nail color decorative color diagnostic board; ${ }^{3)}$ Personal color diagnostic heaven. 
에게 적합한 컬러시스템을 기준으로 선택하였으며, 퍼스널컬러 유형 별 각 유형을 구분할 수 있는 한국인의 신체 색에 가장 조화로운 퍼스 널컬러를 객관적인 기준으로 제안하기 위해 가장 적합하다 사료되었 다. 대표 색상은 측색계로 컬러를 측정 후 수치화 된 데이터를 $\mathrm{L}^{*}$ (명 도), $\mathrm{a}^{*}$ (적색도), $\mathrm{b}^{*}$ (황색도)값을 기준으로 분류한 다음 배색측정 방법 으로 유사한 색상이나 측정값의 차이가 적은 컬러를 제외한 대표 20 가지의 컬러를 선정하여 분류하였다. 컬러 젤은 $\mathrm{A}$ 사 제품 중 현재 시 판되고 있는 제품을 선택하여 바른 후 각 컬러 마다 측색계를 이용하 여 표본 측정값의 오차 범위를 줄이기 위해 3 차례에 걸친 측정을 하 여 그 평균값을 사용하였으며, 그 측정값을 기준으로 컬러를 분류하 고 대표색을 선정하여 컬러 차트 자료로 사용하였다. 따라서 본 연 구에서는 $\mathrm{KS}$ 톤의 퍼스널컬러 유형 별 톤을 선택하여 봄(light), 여름 (whitish), 가을(dull), 겨울(dark) 4계절과 KS 톤의 5원색인 빨강, 노 랑, 초록, 파랑, 보라 컬러를 선정하여 2 색 배색에서 손과 발의 조화 도에 영향을 미치는 요인들을 각 퍼스널컬러 유형에 따라 각 상관관 계를 파악하고 유형 별 톤의 조화도 요인의 분석을 하기 위한 진단의 기준을 제시하고자 하였다. 본 연구의 퍼스널컬러 네일 팁은 Table 2 과 같다.

\section{4) 네일 인조팁 적용 방법}

연구대상자의 퍼스널 네일과 패디 컬러를 파악하기 위한 방법으로 네일 컬러팁을 활용하여 대상자에게 손등의 피부색과 발등의 피부색 의 어울리는 계절 별 유형을 분류하였다. 퍼스널 네일 컬러를 진단하 는 과정은 우선, 각 계절별로 5가지 네일 퍼스널 키트(nail personal color kit)선정하여 시감비색측정을 통하여 어울리는 계절의 색상(best color)과 어울리지 않는 계절의 색상(worst color)를 분류하여 손등과 발등 색상을 봄(light), 여름(whitish), 가을(dull), 겨울(dark) 사계절 타입 중 하나 타입으로 분류하였다. 네일컬러 팁의 적용 방법은 연구 대상자의 손톱과 발톱에 5 개에 팁을 붙여 사용하였으며 이는 손과 발
에 젤 네일을 바르는 과정을 단축시킬 수 있으며 같은 모양과 길이의 손톱과 발톱으로 시 감각의 형태적인 면의 영향이 적어지도록 하였 다.

\section{5) 설문지}

본 연구에서 네일아트와 패디 컬러를 이용한 퍼스널 컬러 분류 연 구를 위해 사용된 육안 측색치와 시험 전후 설문지는 일반적 특성에 대한 측정도구로 Hong (2016)을 바탕으로 연구문항을 구성하였으 며, 이미지스타일에 관한 항목은 Choi \& Suh (2020)의 연구, 퍼스널 컬러 인식에 관한 항목으로는 Lee \& Kim (2020)의 연구, 퍼스널컬러 진단 후 네일과 패디컬러 일치도와 만족도는 Lee \& Kwon (2019), 퍼 스널컬러 후 심리적 변화의 대한 설문 연구 인식에 관한 항목은 You $\& \operatorname{Kim}$ (2020)의 선행연구에서 실시된 측정항목을 토대로 본 연구의 목적에 맞게 문항을 수정, 보완하여 재구성하여 제작한 설문지를 사 용하였다. 또한 시험 전 설문지는 크게 3가지 요인으로, 인구통계학 적 특성 11 문항, 이미지스타일 22 문항, 퍼스널 네일 인식 29 문항으로 구성하였으며, 진단 후 설문지는 2 가지 요인으로 퍼스널컬러 진단 후 네일과 패디컬러 일치도와 만족도 15 문항, 퍼스널컬러 진단 후 심리 적 변화 12 문항으로 각각 구성하여 총 89 문항으로 구성하였다.

\section{6) 자료분석}

본 연구의 수집된 자료는(statistical package for the social science, SPSS) WIN 25.0 프로그램을 이용하여 분석하였다. 분석기 법으로는 연구대상자의 일반적 특성을 파악하기 위해 빈도분석을 실 시하였다. 또한 퍼스널 컬러 진단 유형에 따라 여성들의 피부와 손, 발의 $\mathrm{L}^{*}, \mathrm{a}^{*}, \mathrm{~b}^{*}$ 값과 퍼스널 컬러 진단에 대한 만족도를 살펴보기 위해 one-way ANOVA (일원변량분석)을 실시하였고, 손과 발의 조화 색 상과 부조화 색상을 알아보기 위해 $\chi^{2}$ (Chi-square) 검증을 실시하 였다.

Table 2. Personal color nail tip

\begin{tabular}{|c|c|c|c|c|c|}
\hline & & Yellow & Green & Blue & Purple \\
\hline \multirow{3}{*}{$\begin{array}{l}\text { Spring } \\
\text { (light) }\end{array}$} & $L^{*} 69.4$ & $L^{*} 85.6$ & $L^{*} 69.5$ & $L^{*} 73.0$ & $L^{*} 71.2$ \\
\hline & $a^{*} 44.3$ & $a^{*}-0.0$ & $a^{*}-43.1$ & $a^{*}-32.6$ & $a^{*} 7.3$ \\
\hline & $b^{*} 21.6$ & $b^{*} 80.5$ & $b^{*} 27.4$ & $b^{*}-12.7$ & $b^{*}-10.8$ \\
\hline \multirow{3}{*}{$\begin{array}{l}\text { Summer } \\
\text { (whitish) }\end{array}$} & $L^{*} 86.6$ & $L^{*} 89.3$ & $L^{*} 86.0$ & $L^{*} 81.3$ & $L^{*} 81.7$ \\
\hline & $a^{*} 7.6$ & $a^{*}-1.8$ & $a^{*}-18.6$ & $a^{*}-23.0$ & $a^{*} 4.4$ \\
\hline & $b^{*} 13.8$ & $b^{*} 30.0$ & $b^{*} 18.8$ & $b^{*}-5.4$ & $b^{*}-4.6$ \\
\hline \multirow{3}{*}{$\begin{array}{l}\text { Autumn } \\
\text { (dull) }\end{array}$} & $L^{*} 52.0$ & $L^{*} 55.8$ & $L^{*} 69.4$ & $L^{*} 69.4$ & $L^{*} 49.8$ \\
\hline & $a^{*} 10.7$ & $a^{*} 2.2$ & $a^{*} 44.3$ & $a^{*} 48.0$ & $a^{*} 6.0$ \\
\hline & $b^{*} 8.5$ & $b^{*} 23.8$ & $b^{*} 21.6$ & $b^{*}-18.9$ & $b^{*}-18.8$ \\
\hline \multirow{3}{*}{$\begin{array}{l}\text { Winter } \\
\text { (dark) }\end{array}$} & $L^{*} 31.2$ & $L^{*} 32.9$ & $L^{*} 69.4$ & $L^{*} 34.8$ & $\mathrm{~L}^{*} 27.9$ \\
\hline & $a^{*} 16.1$ & $a^{*} 2.9$ & $a^{*} 44.3$ & $a^{*}-8.9$ & $a^{*} 7.9$ \\
\hline & $b^{*} 5.3$ & $b^{*} 10.2$ & $b^{*} 21.6$ & $b^{*} 7.7$ & $b^{*}-5.0$ \\
\hline
\end{tabular}




\section{Results and Discussion}

\section{1. 연구대상}

본 연구의 연구대상자의 일반적 특성은 Table 3 과 같다.

총 32명 중 연령별로는 30-39세와 40-49세가 각각 $28.1 \%$ 로 가 장 많았으며, 다음으로 20-29세와 50세 이상이 각각 21.9\%를 차지 하였다. 결혼여부별로는 미혼과 기혼이 각각 $50.0 \%$ 로 동일한 분포 를 보였다. 거주 지역별로는 서울이 $84.4 \%$ 로 대부분을 차지하였으 며, 다음으로 경기도 $9.4 \%$, 인천 $6.3 \%$ 순이었다. 최종학력별로는 4 년제 대학교 재학/졸업이 $40.5 \%$ 로 가장 많았으며, 다음으로 고등학 교 졸업 $21.9 \%, 2$ 년제 대학교 재학/졸업과 대학원 재학/졸업이 각각 $18.8 \%$ 로 나타났다.

직업별로는 전문직이 $28.1 \%$ 로 가장 높은 분포를 보였으며, 다
음으로 자영업 $25.0 \%$, 사무직 $21.9 \%$, 판매/서비스직 $12.5 \%$, 학생 $9.4 \%$, 전업주부 $3.1 \%$ 순이었다. 월평균 소득별로는 100 만원 미만이 $43.7 \%$ 로 가장 많았으며, 다음으로 200-300만원 미만 21.9\%, 400 만원 이상 $15.6 \%, 100-200$ 만원 미만과 200-400만원 미만이 각각 $9.4 \%$ 순으로 나타났다. 진단받은 퍼스널 컬러 유형별로는 봄과 여 름, 가을, 겨울 유형이 각각 $25.0 \%$ 를 차지하였다.

\section{2. 퍼스널 컬러 유형에 따른 피부색 $L^{*}, a^{*}, b^{*}$ 값}

여성들의 진단받은 퍼스널 컬러 유형에 따라 피부와 손, 발의 L*, $a^{*}, b^{*}$ 값에 대해 살펴본 결과는 Table 4 와 같다.

먼저 $\mathrm{L}^{*}$ 값을 보면, 피부의 $\mathrm{L}^{*}$ 값은 여름 유형이 가장 높았고, 가 을 유형은 다른 유형보다 낮았으며, 진단받은 퍼스널 컬러 유형에 따 라 유의미한 차이를 보였다 $(F=25.59, p<0.001)$. 손의 L"값 $(F=5.80$,

Table 3. Research subjects' general characteristics

\begin{tabular}{|c|c|c|c|}
\hline & Classification & Frequency & Percentage (\%) \\
\hline \multirow{4}{*}{ Age } & 20-29 years old & 7 & 21.9 \\
\hline & $30-39$ years old & 9 & 28.1 \\
\hline & $40-49$ years old & 9 & 28.1 \\
\hline & More than 50 years old & 7 & 21.9 \\
\hline \multirow{2}{*}{ Marital status } & Unmarried & 16 & 50.0 \\
\hline & Married & 16 & 50.0 \\
\hline \multirow{3}{*}{ Residential area } & Seoul & 27 & 84.4 \\
\hline & Incheon & 2 & 6.3 \\
\hline & Gyeonggi Province & 3 & 9.4 \\
\hline \multirow{4}{*}{ Final academic background } & High school graduation & 7 & 21.9 \\
\hline & 2-year college student/graduation & 6 & 18.8 \\
\hline & 4-year university student/graduation & 13 & 40.5 \\
\hline & Graduate school student/graduation & 6 & 18.8 \\
\hline \multirow{6}{*}{ Job } & Clerical work & 7 & 21.9 \\
\hline & Profession & 9 & 28.1 \\
\hline & Sales/service job & 4 & 12.5 \\
\hline & Self-employed & 8 & 25.0 \\
\hline & Student & 3 & 9.4 \\
\hline & Housewife & 1 & 3.1 \\
\hline \multirow{5}{*}{ Average monthly income } & Under 1 million won & 14 & 43.7 \\
\hline & 1 million won-Below 2 million won & 3 & 9.4 \\
\hline & 2 million won-Less than 3 million won & 7 & 21.9 \\
\hline & 3 million won-Under 4 million won & 3 & 9.4 \\
\hline & Above 4 million won & 5 & 15.6 \\
\hline \multirow{5}{*}{ Diagnosed personal color type } & Spring & 8 & 25.0 \\
\hline & Summer & 8 & 25.0 \\
\hline & Autumn & 8 & 25.0 \\
\hline & Winter & 8 & 25.0 \\
\hline & Total & 32 & 100.0 \\
\hline
\end{tabular}


$p<0.01)$ 과 발의 $\mathrm{L}^{*}$ 값 $(F=8.53, p<0.001)$ 은 겨울 유형이 가장 높았고, 가을 유형은 다른 유형보다 낮았으며, 통계적으로도 유의미한 차이를 보였다.

다음으로 $\mathrm{a}^{*}$ 값을 보면, 피부의 $\mathrm{a}^{*}$ 값은 가을 유형이 가장 높았고, 봄 유형은 다른 유형보다 낮았으며, 진단받은 퍼스널 컬러 유형에 따라 유의미한 차이를 보였다 $(F=15.94, p<0.001)$. 손의 $\mathrm{a}^{*}$ 값은 가을 유형 이 가장 높았고, 여름 유형은 다른 유형보다 낮았으며, 통계적으로도 유의미한 차이를 보였다( $F=7.30, p<0.01)$. 발의 $\mathrm{a}^{*}$ 값은 가을 유형이 가장 높았고, 겨울 유형은 다른 유형보다 낮았으며, 진단받은 퍼스널 컬러 유형에 따라 유의미한 차이를 보였다 $(F=3.85, p<0.05)$.

또한 $\mathrm{b}^{*}$ 값을 보면, 피부의 $\mathrm{b}^{*}$ 값 $(F=27.33, p<0.001)$ 과 손의 $\mathrm{b}^{*}$ 값 ( $F=14.05, p<0.001)$, 발의 $\mathrm{b}^{*}$ 값 $(F=10.18, p<0.001)$ 은 가을 유형이 가 장 높았고, 겨울 유형은 다른 유형보다 낮았으며, 통계적으로도 유의 미한 차이를 보였다.

전체적으로 $\mathrm{L}^{*}$ 값은 여름 유형이 가장 높았고, 가을 유형은 다른 유
형보다 낮았으며, 진단받은 퍼스널 컬러 유형에 따라 유의미한 차이 를 보였다( $F=13.84, p<0.001), \mathrm{a}^{*}$ 값은 가을 유형이 가장 높았고, 봄 유형은 다른 유형보다 낮았으며, 통계적으로도 유의미한 차이를 보였 다 $(F=14.62, p<0.001) . \mathrm{b}^{\star}$ 값은 가을 유형이 가장 높았고, 겨울 유형은 다른 유형보다 낮았으며, 진단받은 퍼스널 컬러 유형에 따라 유의미한 차 이를 보였다( $F=26.36, p<0.001)$.

이상과 같이 여름 유형이 다른 유형보다 피부의 $\mathrm{L}^{*}$ 값이 높고, 겨울 유형은 다른 유형보다 손과 발의 L'값이 높으며, 가을 유형은 다른 유 형보다 피부와 손, 발의 $\mathrm{a}$ 값과 $\mathrm{b}$ 값이 높음을 알 수 있다.

\section{3. 손과 발의 조화와 부조화 색상}

1) 손의 조화와 부조화의 톤과 색상

(1) 손의 조화 톤과 색상

여성들이 진단받은 퍼스널 컬러 유형에 따라 손의 부조화 톤과 색 상에 대해 살펴본 결과는 Table 5 과 같다.

Table 4. Values of $L^{*}, a^{*}, b^{*}$ in skin, hands and feet depending on a personal color type

\begin{tabular}{|c|c|c|c|c|c|c|c|c|c|c|c|}
\hline \multirow{2}{*}{\multicolumn{2}{|c|}{ Classification }} & \multicolumn{2}{|c|}{ Spring (light) } & \multicolumn{2}{|c|}{ Summer (whitish) } & \multicolumn{2}{|c|}{ Autumn (dull) } & \multicolumn{2}{|c|}{ Winter (dark) } & \multirow{2}{*}{$F$} & \multirow{2}{*}{$p$} \\
\hline & & $M$ & SD & $M$ & SD & $M$ & SD & $M$ & SD & & \\
\hline \multirow{3}{*}{$L^{*}$} & Skin & 66.34 & 1.55 & 66.90 & 2.04 & 60.05 & 1.75 & 62.41 & 1.93 & $25.59^{* * *}$ & 0.000 \\
\hline & Hand & 64.12 & 4.68 & 64.78 & 3.36 & 58.87 & 2.68 & 64.82 & 2.24 & $5.80^{* *}$ & 0.003 \\
\hline & Feet & 65.41 & 3.20 & 66.65 & 3.46 & 61.14 & 1.91 & 68.07 & 2.76 & $8.53^{* * *}$ & 0.000 \\
\hline \multirow{3}{*}{$a^{*}$} & Skin & 14.13 & 1.53 & 14.95 & 1.38 & 17.63 & 0.50 & 17.60 & 1.44 & $15.94^{* * *}$ & 0.000 \\
\hline & Hand & 14.12 & 2.26 & 13.84 & 1.75 & 17.41 & 1.74 & 14.30 & 1.06 & $7.30^{* *}$ & 0.001 \\
\hline & Feet & 12.87 & 1.85 & 13.20 & 1.70 & 14.79 & 2.20 & 11.75 & 1.41 & $3.85^{*}$ & 0.020 \\
\hline \multirow{3}{*}{$b^{*}$} & Skin & 23.90 & 1.21 & 20.12 & 3.35 & 29.30 & 1.45 & 19.28 & 3.10 & $27.33^{* * *}$ & 0.000 \\
\hline & Hand & 23.22 & 1.51 & 21.22 & 2.88 & 26.69 & 2.97 & 19.60 & 1.34 & $14.05^{* * *}$ & 0.000 \\
\hline & Feet & 19.81 & 1.87 & 16.63 & 3.10 & 22.55 & 2.41 & 16.33 & 2.87 & $10.18^{* * *}$ & 0.000 \\
\hline \multirow{3}{*}{ Total } & $L^{*}$ & 65.29 & 2.71 & 66.11 & 2.42 & 60.02 & 1.61 & 65.10 & 1.41 & $13.84^{* * *}$ & 0.000 \\
\hline & $a^{*}$ & 13.71 & 1.00 & 13.99 & 0.89 & 16.61 & 1.16 & 14.55 & 0.79 & $14.62^{* * *}$ & 0.000 \\
\hline & $b^{*}$ & 22.31 & 0.89 & 19.33 & 2.70 & 26.18 & 1.96 & 18.40 & 1.73 & $26.36^{* * *}$ & 0.000 \\
\hline
\end{tabular}

${ }^{*} p<0.05 ;{ }^{* *} p<0.01 ;{ }^{* * *} p<0.001 ; \mathrm{M}$, mean; SD, standard deviation.

Table 5. Matched tone and color in hands

\begin{tabular}{|c|c|c|c|c|c|c|c|}
\hline & Classification & Spring (light) & Summer (whitish) & Autumn (dull) & Winter (dark) & $x^{2}$ & $p$ \\
\hline \multirow{4}{*}{ Tone } & Spring & $8(100.0)$ & $0(0.0)$ & $0(0.0)$ & $0(0.0)$ & \multirow{4}{*}{$96.00^{* * *}(9)$} & \multirow{4}{*}{0.000} \\
\hline & Summer & $0(0.0)$ & $8(100.0)$ & $0(0.0)$ & $0(0.0)$ & & \\
\hline & Autumn & $O(0.0)$ & $0(0.0)$ & $8(100.0)$ & $0(0.0)$ & & \\
\hline & Winter & $\mathrm{O}(0.0)$ & $0(0.0)$ & $0(0.0)$ & $8(100.0)$ & & \\
\hline \multirow{4}{*}{ Color } & Red & $2(25.0)$ & $1(12.5)$ & $7(87.5)$ & $1(12.5)$ & \multirow{4}{*}{$39.30^{* * *}(9)$} & \multirow{4}{*}{0.000} \\
\hline & Purple & $\mathrm{O}(0.0)$ & $7(87.5)$ & $0(0.0)$ & $6(75.0)$ & & \\
\hline & Yellow & $6(75.0)$ & $0(0.0)$ & $0(0.0)$ & $1(12.5)$ & & \\
\hline & Green & $\mathrm{O}(0.0)$ & $0(0.0)$ & $1(12.5)$ & $0(0.0)$ & & \\
\hline Total & & $8(100.0)$ & $8(100.0)$ & $8(100.0)$ & $8(100.0)$ & & \\
\hline
\end{tabular}


먼저 손의 조화 톤을 보면, 퍼스널 컬러 진단 유형별로는 봄 유 형은 다른 유형보다 손의 조화 톤으로 웜톤의 봄 유형이 많았고, 여름 유형 유형은 다른 유형보다 쿨톤의 여름 유형이, 가을 유형은 웜톤의 가을 유형이, 겨울 유형은 다른 유형보다 쿨톤의 겨울 유형 이 많았고, 퍼스널 컬러 진단 유형에 따라 유의미한 차이를 보였다 $\left(\chi^{2}=96.00, p<0.001\right)$.

다음으로 손의 색상 조화를 보면, 퍼스널 컬러 진단 유형별로는 봄 유형은 다른 유형보다 손의 조화 색상으로 노랑색이 많았고, 여름 유 형은 다른 유형보다 보라색이 많았으며, 가을 유형은 다른 유형보다 빨강색이 많았고, 퍼스널 컬러 진단 유형에 따라 유의미한 차이를 보 였다 $\left(\chi^{2}=39.30, p<0.001\right)$.

(2) 손의 부조화 톤과 색상

여성들이 퍼스널 컬러 진단 유형에 따라 손의 부조화 톤과 색상에 대해 살펴본 결과는 Table 6 와 같다.

먼저 손의 부조화 톤을 보면, 퍼스널 컬러 진단 유형별로는 봄 유형 과 여름 유형이 다른 유형보다 손의 부조화 색상으로 쿨톤의 겨울 유 형이 많았고, 가을 유형은 다른 유형보다 쿨톤의 여름 유형이 많았으 며, 겨울 유형은 다른 유형보다 쿨톤의 여름 유형이 많았고, 퍼스널 컬 러 진단 유형에 따라 유의미한 차이를 보였다 $\left(\chi^{2}=35.52, p<0.001\right)$.

다음으로 손의 부조화 색상을 보면, 퍼스널 컬러 진단 유형별로는
봄 유형과 여름 유형이 다른 유형보다 손의 부조화 색상으로 노랑색이 많았고, 가을 유형과 겨울 유형은 다른 유형보다 빨강색이 많았으며, 퍼스널 컬러 진단 유형에 따라 유의미한 차이를 보였다 $\left(\chi^{2}=31.06\right.$, $p<0.001)$.

2) 발의 조화와 부조화의 톤과 색상

(1) 발의 조화 톤과 색상

여성들이 퍼스널 컬러 진단 유형에 따라 발의 부조화 톤과 색상에 대해 살펴본 결과는 Table 7와 같다.

먼저 발의 조화 톤을 보면, 퍼스널 컬러 진단 유형별로는 봄 유 형은 다른 유형보다 발의 조화 톤으로 윔톤의 봄 유형이 많았고, 여 름 유형 유형은 다른 유형보다 쿨톤의 여름 유형이, 가을 유형은 웜 톤의 가을 유형이, 겨울 유형은 다른 유형보다 쿨톤의 겨울 유형 이 많았고, 퍼스널 컬러 진단 유형에 따라 유의미한 차이를 보였다 $\left(\chi^{2}=96.00, p<0.001\right)$.

다음으로 발의 조화 색상을 보면, 퍼스널 컬러 진단 유형별로는 봄 유형은 다른 유형보다 발의 조화 색상으로 노랑색이 많았고, 여름 유형은 다른 유형 보다 보라(가 많았으며, 가을 유형은 다른 유형보 다 빨강색이 많았으며, 겨울 유형은 다른 유형보다 보라색이 많았고, 퍼스널 컬러 진단 유형에 따라 유의미한 차이를 보였다 $\left(\chi^{2}=44.58\right.$, $p<0.001)$.

Table 6. Unmatched tone and color in hands

\begin{tabular}{|c|c|c|c|c|c|c|c|}
\hline & Classification & Spring (light) & Summer (whitish) & Autumn (dull) & Winter (dark) & $x^{2}$ & $p$ \\
\hline \multirow{3}{*}{ Tone } & Summer & $0(0.0)$ & $0(0.0)$ & $8(100.0)$ & $5(62.5)$ & \multirow{3}{*}{$35.52^{* * *}(6)$} & \multirow{3}{*}{0.000} \\
\hline & Autumn & $0(0.0)$ & $1(12.5)$ & $0(0.0)$ & $3(37.5)$ & & \\
\hline & Winter & $8(100.0)$ & $7(87.5)$ & $0(0.0)$ & $0(0.0)$ & & \\
\hline \multirow{4}{*}{ Color } & Red & $0(0.0)$ & $0(0.0)$ & $4(50.0)$ & $5(62.5)$ & \multirow{4}{*}{$31.06^{* * *}(9)$} & \multirow{4}{*}{0.000} \\
\hline & Purple & $0(0.0)$ & $0(0.0)$ & $2(25.0)$ & $0(0.0)$ & & \\
\hline & Yellow & $8(100.0)$ & $8(100.0)$ & $0(0.0)$ & $3(37.5)$ & & \\
\hline & Blue & $0(0.0)$ & $0(0.0)$ & $2(25.5)$ & $0(0.0)$ & & \\
\hline Total & & $8(100.0)$ & $8(100.0)$ & $8(100.0)$ & $8(100.0)$ & & \\
\hline
\end{tabular}

Table 7. Matched tone and color in feet

\begin{tabular}{|c|c|c|c|c|c|c|c|}
\hline & Classification & Spring (light) & Summer (whitish) & Autumn (dull) & Winter (dark) & $x^{2}$ & $p$ \\
\hline \multirow{4}{*}{ Tone } & Spring & $8(100.0)$ & $0(0.0)$ & $0(0.0)$ & $0(0.0)$ & \multirow{4}{*}{$96.00^{* * *}(9)$} & \multirow{4}{*}{0.000} \\
\hline & Summer & $0(0.0)$ & $8(100.0)$ & $0(0.0)$ & $0(0.0)$ & & \\
\hline & Autumn & $0(0.0)$ & $0(0.0)$ & $8(100.0)$ & $0(0.0)$ & & \\
\hline & Winter & $0(0.0)$ & $0(0.0)$ & $0(0.0)$ & $8(100.0)$ & & \\
\hline \multirow{3}{*}{ Color } & Red & $0(0.0)$ & $1(12.5)$ & $8(100.0)$ & $1(12.5)$ & \multirow{3}{*}{$44.58^{* * *}(6)$} & \multirow{3}{*}{0.000} \\
\hline & Purple & $0(0.0)$ & $4(50.5)$ & $0(0.0)$ & $7(85.0)$ & & \\
\hline & Yellow & $8(100.0)$ & $3(37.5)$ & $0(0.0)$ & $0(0.0)$ & & \\
\hline Total & & $8(100.0)$ & $8(100.0)$ & $8(100.0)$ & $8(100.0)$ & & \\
\hline
\end{tabular}


(2) 발의 부조화

여성들이 퍼스널 컬러 진단 유형에 따라 발의 부조화 톤과 색상에 대해 살펴 본 결과는 Table 8과 같다.

먼저 발의 부조화 톤을 보면, 퍼스널 컬러 진단 유형별로는 봄 유 형과 여름 유형이 다른 유형보다 발의 부조화 색상으로 쿨톤의 겨울 유형이 많았고, 가을 유형은 다른 유형보다 쿨톤의 여름 유형이 많았 으며, 겨울 유형은 다른 유형보다 웜톤의 여름과 가을 유형이 많았고 가을 유형이 많았고, 퍼스널 컬러 진단 유형에 따라 유의미한 차이를 보였다 $\left(\chi^{2}=38.40, p<0.001\right)$.

다음으로 발의 부조화 색상을 보면, 퍼스널 컬러 진단 유형별로는 봄 유형이 다른 유형보다 발의 부조화 색상으로 노랑색이 많았고, 여 름 유형은 다른 유형 보다 노랑이 많았으며, 가을 유형은 다른 유형 보다 빨강색과 보라색이 많았으며, 겨울 유형은 다른 유형보다 노랑 이 많은 것으로 퍼스널 컬러 진단 유형에 따라 유의미한 차이를 보였 다 $\left(\chi^{2}=20.00, p<0.05\right)$.

\section{4. 퍼스널 컬러 진단에 대한 만족도}

여성들의 퍼스널 컬러 진단 유형에 따라 퍼스널 컬러에 대한 만족 도에 대해 살펴본 결과는 Table 9 와 같다.
퍼스널 컬러 진단에 대한 만족도 $(F=3.90, p<0.05)$ 와 퍼스널 네일 컬러 진단에 대한 만족도 $(F=6.06, p<0.01)$ 는 봄 유형이 가장 높았고, 겨울 유형은 다른 유형보다 낮았으며, 퍼스널 컬러 지단 유형에 따라 유의미한 차이를 보였다. 퍼스널 페디 컬러 진단에 대한 만족도는 봄 유형이 가장 높았고, 겨울 유형은 다른 유형보다 낮았으나 유의미한 차이는 아니었다. 퍼스널 컬러 진단이 뷰티스타일링에 미치는 영향 에 대해서는 봄 유형이 가장 높은 인식을 보였고, 겨울 유형은 다른 유형보다 낮은 인식을 보였으며, 통계적으로도 유의미한 차이를 보 였다 $(F=3.88, p<0.05)$.

이상과 같이 봄 유형이 다른 유형보다 퍼스널 컬러 진단에 대한 만 족도와 퍼스널 네일 컬러 진단에 대한 만족도가 높으며, 퍼스널 컬러 진단은 뷰티스타일링에 미치는 영향에 대해서도 높은 인식을 보이고 있음을 알 수 있다.

\section{Conclusion}

본 연구는 여성들의 패션의 퍼스널 컬러를 진단하고, 진단한 패션 의 퍼스컬 컬 러와 네일 및 페디큐어 컬러 매칭의 상관성을 밝힘으로

Table 8. Unmatched tone and color in feet

\begin{tabular}{|c|c|c|c|c|c|c|c|}
\hline & Classification & Spring (light) & Summer (whitish) & Autumn (dull) & Winter (dark) & $x^{2}$ & $p$ \\
\hline \multirow{3}{*}{ Tone } & Summer & $0(0.0)$ & $0(0.0)$ & $8(100.0)$ & $4(50.0)$ & \multirow{3}{*}{$38.40^{* * *}(6)$} & \multirow{3}{*}{0.000} \\
\hline & Autumn & $0(0.0)$ & $1(12.5)$ & $0(0.0)$ & $4(50.0)$ & & \\
\hline & Winter & $8(100.0)$ & $7(87.5)$ & $0(0.0)$ & $0(0.0)$ & & \\
\hline \multirow{4}{*}{ Color } & Red & $0(0.0)$ & $1(12.5)$ & $5(62.5)$ & $3(37.5)$ & \multirow{4}{*}{$20.00^{*}(9)$} & \multirow{4}{*}{0.000} \\
\hline & Purple & $0(0.0)$ & $1(12.5)$ & $2(25.0)$ & $0(0.0)$ & & \\
\hline & Yellow & $8(100.0)$ & $6(75.0)$ & $0(0.0)$ & $4(50.5)$ & & \\
\hline & Blue & $0(0.0)$ & $0(0.0)$ & $1(12.5)$ & $1(12.5)$ & & \\
\hline Total & & $8(100.0)$ & $8(100.0)$ & $8(100.0)$ & $8(100.0)$ & & \\
\hline
\end{tabular}

${ }^{*} p<0.05 ;{ }^{* * *} p<0.001$.

Table 9. Satisfaction with the diagnosed personal color

\begin{tabular}{|c|c|c|c|c|c|c|c|c|c|c|c|c|}
\hline \multirow{2}{*}{ Classification } & \multicolumn{2}{|c|}{ Spring (light) } & \multicolumn{2}{|c|}{ Summer (whitish) } & \multicolumn{2}{|c|}{ Autumn (dull) } & \multicolumn{2}{|c|}{ Winter (dark) } & \multicolumn{2}{|c|}{ Total } & \multirow{2}{*}{$F$} & \multirow{2}{*}{$p$} \\
\hline & M & SD & M & SD & M & SD & M & SD & M & SD & & \\
\hline $\begin{array}{l}\text { Satisfaction with the } \\
\text { diagnosed personal } \\
\text { color }\end{array}$ & 4.68 & 0.51 & 4.63 & 0.42 & 4.23 & 0.23 & 3.98 & 0.65 & 4.38 & 0.54 & $3.90^{*}$ & 0.019 \\
\hline $\begin{array}{l}\text { Satisfaction at the } \\
\text { diagnosed personal } \\
\text { nail color }\end{array}$ & 4.75 & 0.37 & 4.13 & 0.53 & 4.10 & 0.30 & 3.90 & 0.45 & 4.22 & 0.52 & $6.06^{* *}$ & 0.003 \\
\hline $\begin{array}{l}\text { Satisfaction at the } \\
\text { diagnosed personal } \\
\text { Pedicure color }\end{array}$ & 4.38 & 0.42 & 4.33 & 0.59 & 3.95 & 0.44 & 3.78 & 0.52 & 4.11 & 0.54 & 2.74 & 0.062 \\
\hline $\begin{array}{l}\text { Influence of the } \\
\text { diagnosed personal } \\
\text { color upon beauty } \\
\text { styling }\end{array}$ & 4.49 & 0.36 & 4.43 & 0.55 & 3.95 & 0.53 & 3.72 & 0.66 & 4.15 & 0.61 & $3.88^{*}$ & 0.019 \\
\hline
\end{tabular}

${ }^{*} p<0.05 ;{ }^{* *} p<0.01 ; \mathrm{M}$, mean; SD, standard deviation. 
써 여성들의 뷰티 이미지 향상에 유용한 정보를 제공하고자 건국대학 교 기관생명윤리위원회(IRB)의 연구 승인(7001355-202103-HR427)을 받고 진행하였다.

연구대상으로는 수도권에 거주하는 20-50세의 여성을 대상으로 2021년 5월 15일부터 5월 16일까지 이틀 동안 피부측정을 통하여 4 계절 유형을 토대로 빨강, 노란색, 초록, 파랑, 보라, 5 가지 피부의 톤을 분류하여 퍼스널 컬러 진단 시험을 실시하였다. 또한 퍼스널컬 러에 대한 만족도와 퍼스널 네일 컬러에 대한 만족도는 시험 전·후 설문지를 통하여 조사하였다. 수집된 자료는 SPSS WIN 25.0 프로 그램을 이용하여 빈도분석, $\chi^{2}$ 검증, One-way ANOVA을 실시하였 으며, 그 결과는 다음과 같다.

첫째, 여성들의 퍼스널컬러 진단 컬러 유형에 따라 피부와 손, 발 의 $\mathrm{L}^{*}, \mathrm{a}^{*}, \mathrm{~b}^{*}$ 값을 측정한 결과, 여름 유형이 피부의 $\mathrm{L}^{*}$ 값이 가장 높았 고, 겨울 유형이 손과 발의 L"값이 높았으며, 가을 유형이 피부와 손, 발의 $\mathrm{a}^{*}$ 와 $b^{*}$ 값이 높았다. Lee \& Kwon (2017)의 연구결과 손등의 컬러 유형과 얼굴색의 유형이 서로 다를 수 있는 결과에 대한 것을 시 사하였고, 손과 발의 밝기의 차이는 유의미한 차이가 거의 없었다.

둘째, 손과 발의 조화 톤은 퍼스널 컬러 중 봄 유형은 윔톤의 봄 유 형이, 여름 유형은 쿨톤의 여름 유형이, 가을 유형은 윔톤의 가을 유 형이, 겨울 유형은 쿨톤의 겨울 유형이 많았다. 또한 손과 발의 조화 색상은 퍼스널 컬러 유형 중 봄 유형은 다른 유형보다 노란색이 많았 고, 가을 유형은 다른 유형보다 빨강색이 많았다. 이와 같은 결과는 퍼스널컬러의 베이스컬러에 따라 옐로 베이스는 따뜻한 유형의 봄과 가을, 블루베이스는 차가운 유형으로 여름과 겨울이 이에 속하여 사 계절 유형으로 구분되며(Shin \& Park, 2015), 유형별 계절의 어울리 는 색으로는 같은 베이스의 같은 유형이 조화로운 색이다.

셋째, 손과 발의 부조화 톤은 퍼스널 컬러 유형 중 봄 유형과 여름 유형이 쿨톤의 겨울 유형이, 가을 유형은 쿨톤의 여름 유형이, 겨울 유형은 웜톤의 가을 유형이 많았다. 또한 손의 부조화 색상으로는 퍼 스널 컬러 중 봄 유형과 여름 유형이 노란색이 많았고, 겨울 유형은 빨강색이 많았으며, 발의 부조화 색상은 퍼스널 컬러 유형 중 봄 유 형이 노란색이 많았고, 가을 유형은 빨강색과 보라색이 많았다. 이와 같은 결과는 퍼스널컬러의 베이스컬러에 따라 옐로 베이스는 따뜻한 유형의 봄과 가을, 블루베이스는 차가운 유형으로 여름과 겨울이 이 에 속하여 사계절 유형으로 구분된다(Shin \& Park, 2015).

넷째, 퍼스널컬러 유형에 따른 퍼스널컬러 진단에 대한 만족도에 대해 살펴본 결 과, 퍼스널 컬러 중 봄 유형이 다른 유형보다 퍼스널 컬러 진단에 대한 만족도와 퍼스널 진단 네일 컬러에 대한 만족도가 높았고, 퍼스널 진단 컬러가 뷰티스타일링에 미치는 영향에 대해서 도 높은 인식을 보였다. 이것은 Lee \& Kwon (2017)의 연구 결과에 서 퍼스널 네일 컬러와 네일 컬러링의 일치 여부에 따라 네일 컬러링 에 대한 만족도가 높으며 네일 컬러링에 대한 만족감은 네일 컬러가 자신의 피부색에도 잘 어울린다고 평가하는 결과와 일치하였다.

이상과 같은 연구결과를 통해 손과 발의 조화 톤은 패션의 퍼스널
컬러 유형과 동일하며, 손과 발의 조화와 부조화 색상은 차이가 있음 을 알 수 있다. 즉, 패션의 봄 유형은 손과 발의 봄 유형의 노란색으 로, 가을 유형은 손과 발의 가을 유형의 빨강색으로 손과 발의 조화 색상이 동일하였고, 여름 유형은 손의 여름 유형의 보라색이, 패션의 겨울 유형은 발의 겨울 유형의 보라색으로 손과 발의 조화 색상이 차 이가 있었다. 또한 손과 발의 부조화 톤은 패션의 봄과 여름 유형은 겨울의 노란색이, 가을은 여름의 빨강색으로 손과 발의 부조화 색상 이 동일하였으며, 겨울 유형은 손의 여름 유형의 빨강색이, 발은 가 을 유형의 노란색으로 손과 발의 부조화 색상이 차이가 있었다. 이와 같은 결과를 통하여 네일아트와 페디큐어의 컬러 팁을 이용하여 톤의 4계절 유형의 분류가 가능함을 예측할 수 있다. 또한 자신에게 어울 린다고 진단된 퍼스널 컬러로 컬러링 하였을 경우 손과 발의 피부색 도 더 잘 어울린다고 평가하며, 네일 컬러링에 대한 만족도도 높음을 알 수 있다. 따라서 네일 컬러링의 효과와 고객의 만족도를 극대화하 기 위해서는 개개인의 특성에 맞는 퍼스널 네일 컬러 진단이 우선되 어야 하며, 신체 부위별에 따른 퍼스널 컬러를 바탕으로 자신에게 어 울리는 네일 컬러와 페디큐어 컬러 유형의 파악 및 선택이 이루어져 야 할 것으로 사료된다.

본 연구는 수도권에 거주하는 일부 여성을 대상으로 하였으므로 연구결과를 일반화하기에 무리가 따를 수 있으므로 향후 연구에서는 광범위한 지역을 대상으로 폭 넓은 연구대상의 표집이 이루어질 필요 가 있다. 본 연구는 네일아트와 페디큐어 컬러 선택 시 조화로운 컬 러 매칭의 이론적 근거를 마련하였다는 점에서 의의를 지니며, 감성 시대의 흐름에 맞춰 여성들의 뷰티 스타일링 및 이미지 향상에 유용 한 정보를 제공할 것으로 기대된다.

This work is a part of the sun-he Moon's M.Sc. thesis at the Konkuk University. Seoul. Korea.

\section{Author's contribution}

SHM and YSK designed overall studies and wrote the manuscript together. SHM and YSK analyzed the data. All authors read and confirmed the final version of manuscript.

\section{Author details}

Sun-he Moon (Graduate student). Department of Cosmetics Engineering, Konkuk University, 120 Neungdong-ro Gwangjin-gu, Seoul 05029, Korea and (CEO), Yeoshiya Beauty Academy 99, Sinjeongjungangro, Yangcheon-gu, Seoul 07938, Korea; Yong-Sam Kim (Professor), Department of Image Industry, Graduate School of Engineering, Konkuk University, 120 Neungdong-ro Gwangjin-gu, Seoul 05029, Korea. 


\section{References}

Byun J, Lee YJ. A study on the change of perception after personal color diagnosis and application of job seekers. Journal of the Korea Institute of Spatial Design, 14: 6-53, 2019.

Cho MJ, Analysis of image makeup using color trends. Asian Journal of Beauty and Cosmetology, 4: 499-507, 2018.

Choi HK, Suh SH. A study on the expression elements of fashion styles according to the pursuit image types of the male office worker. Journal of Fashion Business, 4: 30-47, 2020.

Hong DG, Lee HY, Lee JH. A study of differences in hand skin color among Koreans by age. Journal of the Korean Society of Beauty and Art, 53: 163-175, 2016.

Im EJ, Park M, Ha J. The correlation among perception and application of personal color and beauty styling: women in their 20s. Journal of Investigative Cosmetology, 13: 369379, 2017.

Jeun YS, Shim JS. A study of hybrid trend in the makeup design. Asian Journal of Beauty and Cosmetology, 10: 173-177, 2012.

Jung YJ. A study on the image scailing for beauty styling. Journal of the Korean Society of Beauty and Art, 14: 7995, 2013.

Kim JD. A study on the actual condition of using low-priced cosmetics and on the purchasing behavior in female undergraduates. Journal of the Society of Cosmetic Scientists of Korea, 37: 177-189, 2011.

Kim MK. Correlation between the factors of personal color diagnosis guide and brain wave analysis. Asian Journal of Beauty and Cosmetology, 14: 407-416, 2016.

Kim MK, Kim JD. A study on the of beauty styling on personal image making. Journal of the Korean Society of Cosmetics and Cosmetology, 4: 121-138, 2014.

Lee JA, Kim C. The effects of personal color awareness on color cosmetic purchase criteria and purchase behavior. Journal of the Korean Society of Cosmetics and Cosmetology, 26: 635-645, 2020.

Lee JH, Yan YC, Kang S, Suk HJ. Comparative study on facial Color between subjective judgment and colorimetric quantities. Journal of Korea Society of Color Studies, 33: 33-65, 2019.

Lee YE, Park KS. Analysis of facial coloration in accordance with the type of personal color system of female university students. The Research Journal of the Costume Culture, 20: 144-153, 2012.

Lee HW, Kwon HS. The effect of nail-coloring with the personal color on recognition of the body image change and satisfaction of the nail-coloring. Journal of the Korean Society of Beauty and Art, 20: 257-271, 2017.

Moon W, Park Y. Personal color analysis though relation between timber, skin tone and iris color. Journal of Korea society of Color Studies, 28: 15-25, 2014.

Min IS, Park JH, Lim JH, Park EJ. How to uniform satisfaction affected by uniform recognition in the beauty services workers. Asian Journal of Beauty and Cosmetology, 11: 289-296, 2013.

Oh RB, Cho MJ. The development of nail art design utilizing the Panton color trend. Journal of the Korean Society of Cosmetology, 24: 133-142, 2018.

Shin HS, Park YS. A comparative analysis on complexion and skin color in 20s-30s and 40s-50s by frequency of lab values. Journal of the Korean Society of Beauty and Art, 11: 103-113, 2015.

Song SM, Lee KH, Kim JH. Color effects as affected by concentration rate of peariescent pigment in eyeshadows. Journal of the Korean Society of Beauty and Art, 15: 7-20, 2014.

Woo SJ, Kim YS. A study on the point makeup purchasing and using behavior according to the personal color awareness. The Research Journal of the Costume Culture, 19: 889902, 2011 


\section{국문초록}

\section{패션의 퍼스널 컬러와 네일 및 페디큐어의 컬러 매칭과의 상관성 연구}

문선희, 김영삼 ${ }^{2 *}$

${ }^{1}$ 건국대학교 화장품공학과, 서울, 한국

${ }^{2}$ 건국대학교 산업대학원 이미지산업학과, 서울, 한국

목적: 본 연구는 여성들의 패션의 퍼스널 컬러를 진단하고, 진단한 패션의 퍼스컬 컬러와 네일 및 페디큐어 컬러 매칭의 상관성을 밝힘으로써 여성들의 뷰티 이미지 향상에 유용한 정보를 제공하고자 하였다. 방법: 연구대상으로는 수도권에 거주하는 20-50세의 여성 32명을 대상으로 패션의 퍼스널 컬러를 진단하였다. 수집된 자료는 SPSS WIN 25.0을 이용해 빈도분석, $\chi^{2}$ 검증, One-way $\mathrm{ANOVA}$ 을 실시하였다. 결과: 퍼스널 컬러 유형 중 피부의 $\mathrm{L}^{*}$ 값은 여름 유형이, 손과 발의 $\mathrm{L}^{*}$ 값은 겨울 유형이, 피부와 손, 발의 $\mathrm{a}^{*}$ 와 $\mathrm{b}^{\star}$ 값은 가을 유형이 높았다. 또한 손과 발의 조화 톤은 퍼스널 컬러 중 봄 유형은 윔톤의 봄 유형이, 여름 유형은 쿨톤의 여름 유형 이, 가을 유형은 윔톤의 가을 유형이, 겨울 유형은 쿨톤의 겨울 유형이 많았다. 결론: 본 연구결과를 통해 손과 발의 조화 톤은 패션 의 퍼스널 컬러와 동일함을 알 수 있다. 이러한 연구결과는 네일 아트와 페디큐어 컬러 선택 시 조화로운 컬러 매칭의 이론적 근거 를 마련하였고, 감성시대의 흐름에 맞춰 여성들의 뷰티스타일링 및 이미지 향상에 도움을 줄 것으로 기대된다.

핵심어: 퍼스널컬러, 네일, 페디큐어, 뷰티스타일링, 패션

\section{참고문헌}

김민경. 퍼스널 컬러진단 가이드 요인간 상관관계와 뇌파분석. 아시안뷰티화장품학술지, 14: 407-416, 2016. 김민경, 김주덕. 뷰티스타일링이 퍼스널 이미지 메이킹에 미치는 영향. 한국화장품미용학회지, 4: 121-138, 2014. 김주덕. 여대생들의 저가 화장품에 대한 사용실태 및 구매행동에 관한 연구. 대한화장품학회지, 37: 177-189, 2011. 문완묵, 박연선. 음색과 피부색, 홍채색의 상관관계를 통한 퍼스널 컬러 분석. 한국색채학회논문집, 28: 15-25, 2014. 민인숙, 박재홍, 임지현, 박은준. 미용서비스 종사자의 유니폼 인식이 유니폼 개선사항에 미치는 영향. 아시안뷰티화장품

학술지, 11: 289-296, 2013.

변지연, 이윤진. 취업준비생을 대상으로 퍼스널컬러 진단 및 적용 후 인식변화에 관한 연구. 한국공간디자인학회 논문집,

14: 6-53, 2019.

송수미, 김민정, 김정희, 아이새도의 광택 안료 함유량에 따른 발색효과. 한국인체미용예술학회지, 15: 7-20, 2014.

신향선, 박연선. 20-30대와 40-50대 Lab값의 빈도에 따른 얼굴색과 피부색 비교분석. 한국색채학회 논문집, $2: 103-$

$113,2015$.

오란비, 조미자. 컬러트랜드를 활용한 네일아트 디자인 연구: 팬톤의 컬러트랜드를 중심으로. 한국미용학회지, 24: 133142, 2018.

우수진, 김용숙. 퍼스널 컬러 인식에 따른 색조 화장품 구입 및 사용행동. 복식문화연구, 19: 899-902, 2011. 이은영, 박길순. 여대생의 퍼스널컬러 시스템 유형에 따른 얼굴색 분석. 복식문화연구, 20: 144-153, 2012.

이정아, 김찬호. 퍼스널컬러 인식이 색조제품 구매기준 및 구매행동에 미치는 영향, 한국미용학회지, 26: 635-645. 2020.

이주현, 얀유천, 강승현, 석현정. 얼굴 피부색에 대한 주관적 판단과 측색치 간 비교 연구. 한국색채학회 논문집, $33: 33-$ 65, 2019

이현원, 권혜숙. 퍼스널 네일 컬러 진단에 따른 네일 컬러링 일치도가 신체 이미지 변화 인지와 네일 컬러링 만족도에 미치 는 영향. 한국인체미용예술학회지,15: 257-271, 2019. 
임은진, 박명순, 하준호. 퍼스널 컬러의 인식과 활용 및 뷰티스타일링의 상관관계: 20,30 대 여성을 중심으로. 대한미용학 회지, 13: 369-379, 2017.

정연자. 뷰티스타일링을 위한 이미지스케일링에 관한 연구. 한국인체미용예술학회지, 14: 79-95, 2013.

전연숙, 심재숙. 메이크업 디자인에 나타난 하이브리드 트랜드. 아시안뷰티화장품학술지, 10: 173-177, 2012.

조미자. 컬러 트랜드를 활용한 이미지 메이크업 분석. 아시안뷰티화장품학술지, 16: 499-507, 2018.

최현경, 서승희, 직장남서의 추구이미지에 따른 패션스타일 표현요소 연구. 패션비지니스, 4: 30-47, 2020.

한정아. 대학생의 컬러 및 톤의 인지도에 따른 컬러 교육의 필요성에 관한 연구. 한국디자인문화학회지, $16: 557-567$, 2010.

홍다검. 연령에 따른 한국인 손 피부색 차이 분석. 한국인체미용예술학회지, 53: 163-175, 2016. 


\section{中文摘要}

\section{指甲和足部护理中个人时尚色彩选择的研究}

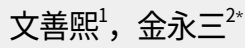

建国大学化妆品工学科, 首尔, 韩国

2建国大学产业大学院影像产业学科, 首尔, 韩国

目的：通过分析女性时尚中的个人色彩选择并确定指甲和足部护理中色彩匹配与个人时尚色彩选择之间的相关 性, 为改善女性的美丽自我形象提供有用的信息。方法: 包括32名居住在首都地区的20-50岁女性作为研究对 象, 确定个人色彩时尚选择。使用SPSS WIN 25.0通过频率分析、 $X^{2}$ 检验和单因素方差分析对数据进行分析。结 果: 考虑到个人颜色选择, 他们的皮肤 L “值的“夏季类型”高, 手脚 L “值的“冬天类型”高, 皮肤以及手和脚的a“和 b“值的“秋季类型”高。另外，在手脚搭配的色调上，个人色彩选择多为“春色”暖春色、夏色暖夏色、“秋色”暖秋 色, 以及“冬季类型” 具有凉爽的冬季类型色调。结论: 这项研究的结果表明, 手脚的匹配色调与个人时尚选择的 颜色相似。这些发现支持了在修指甲和修脚美甲中选择颜色时和谐配色的理论基础。这项研究的结果可能有助 于这个时尚时代女性的美容造型和自我形象。

关键词: 个人色彩, 美甲, 修脚, 美容造型, 时尚 
